\title{
Forest use strategies in watershed management and restoration: application to three small mountain watersheds in Latin America
}

\author{
Juan Ángel Mintegui Aguirre, ${ }^{1}$ José Carlos Robredo Sánchez, ${ }^{1}$ Carlos de Gonzalo Aranoa, ${ }^{1}$ \\ Pablo Huelin Rueda, ${ }^{1}$ Jorge Fallas, ${ }^{2}$ Felipe Cisneros, ${ }^{3}$ Pedro Cisneros, ${ }^{3}$ Adriana Urciuolo, ${ }^{4}$ \\ Rodolfo Iturraspe ${ }^{4}$
}

${ }^{1}$ Department of Forest Engineering, Technical University of Madrid, Spain; ${ }^{2}$ International Center in Economic Policy for the Sustainable Development (CINPE), National University of Costa Rica, San José, Costa Rica; ${ }^{3}$ Water and Soil Management Program (PROMAS), Department of Water and Soil Resources Engineering, University of Cuenca, Ecuador; ${ }^{4}$ National University of Tierra del Fuego, Ushuaia, Argentina

\begin{abstract}
The effect of forests on flow and flood lamination decreases as the magnitude and intensity of torrential events and the watershed surface increase, thus resulting negligible when extreme events affect large catchments. However the effect of forests is advantageous in case of major events, which occur more often, and is particularly effective in soil erosion control. As a result, forests have been extensively used for watershed management and restoration, since they regulate water and sediments cycles, preventing the degradation of catchments.
\end{abstract}

Correspondence: Juan Ángel Mintegui Aguirre, Escuela Técnica Superior de Ingenieros de Montes, Ciudad Universitaria s/n, 28040 Madrid, Spain.

Tel.: + 34.91.336.7118. E-mail: juanangel.mintegui@upm.es

Key words: water and sediments cycle, water and sediments dynamics, forest, watershed management and restoration.

Acknowledgements: this paper summarises the section developed by the team of the Universidad Politécnica de Madrid (Spain) entitled Strategies for water and forest resources management relevant to extreme events, within the framework of the EPIC FORCE project led by Dr. J. C. Bathurst of the University of Newcastle upon Tyne (UK). The authors acknowledge Cristina Maldonado Gallego and Nur Algeet Abarquero (UPM, Spain); Miriam Miranda and Carmen Valverde (Universidad Nacional de Costa Rica) and Marcelo Gaviño, Ramiro Sarandón and Verónica Guerrero Borges (Universidad Nacional de La Plata, Argentina) for their support and participation in the EPIC FORCE project. This was funded by the European Commission within the $6^{\text {th }}$ Framework Program, as a part of the Specific Measures in Support of International Cooperation Programme under the Contract Number INCO-CT2004-510739; to which the authors are very grateful. The project website is http//www.ceg.ncl.ac.uk/epicforce.

Received for publication: 19 November 2013.

Accepted for publication: 8 February 2014.

(C)Copyright J.Á. Mintegui Aguirre et al., 2014

Licensee PAGEPress, Italy

Journal of Agricultural Engineering 2014; XLV:221

doi:10.4081/jae.2014.221

This article is distributed under the terms of the Creative Commons Attribution Noncommercial License (by-nc 3.0) which permits any noncommercial use, distribution, and reproduction in any medium, provided the original author(s) and source are credited.
Introduction

Intensification of water and sediment cycles in watersheds due to the incidence of torrential events

Water reaches watersheds by either ordinary or torrential precipitations and subsequently flows downstream through the drainage network. In particular, major or torrential rainfall events, even when not extreme, pour an enormous water volume in a short period of time, thus increasing the runoff on the slopes and the water flow into the streams, therefore intensifying the water cycle within the watershed. At the same time, also the sediments cycle is activated and triggers erosive processes along the hillsides (impact of raindrops, surface runoff) and channels (abrasion). As a result, a relevant amount of sediments is initially mobilized from the hillsides by the runoff, concentrated in the channels, and subsequently incorporated into the flow, continuing downstream through the drainage network. Finally, when the flow gets to flatter areas, typically located at the dominated areas of the watershed (lowlands), a head loss occurs and the sediment load is deposited. This effect causes either sedimentary fans in torrential streams, or different alluvial deposits in plain rivers. Moreover, under these circumstances, landslides may also occur in the most vulnerable areas of the watershed. This combination of processes, triggered by torrential rainfalls and shown in Figure 1, are hereafter referred as water and sediments dynamics, which may affect the whole watershed and be the cause of natural disasters.

Although every catchment is vulnerable to the water and sediments dynamics, mountain catchments are especially susceptible, because: i) torrential events occur more frequently and are more intensive in mountain areas; ii) mountain watersheds are located at higher altitudes; and iii) steeper slopes are usually present. The water and sediment dynamics start at the headwaters or dominant areas, and spread downstream up to the dominated areas, where they could cause floods and channel aggradation, depending on the event magnitude and intensity.

\section{Protective effect of forests in the basins}

Given the water and sediment cycles intensification, a permanent vegetal cover may be desirable in the dominant areas, if it is compatible with the climatic and soil characteristics, in order to buffer the activation of water and sediment dynamics. If these processes have already been started, forests can partially dissipate its energy, thus reducing its undesirable effects. Well-preserved forests may make this 
possible by playing a role in the above mentioned cycles: i) in the water cycle, the vegetal cover increases the soil surface roughness and permeability and both decreases the runoff velocity and promotes infiltration, thus contributing the flood attenuation; ii) in the sediment cycle, forests can control soil erosion by reducing the concentration of the suspended sediment load and the shear stress of the flow, especially during major floods. In short, forests buffer the intensification of both cycles. This is the reason why reforestation techniques have been widely used to restore mountain watersheds, especially in southern Europe.

Recent studies (Calder et al., 2006, 2007; Bathurst et al., 2010) demonstrated that the efficiency of forests in the lamination of peak flows and floods decreases as the magnitude and intensity of the torrential events and the basin size increase. This effect is negligible in large basins that are significantly affected by extreme events.

Nevertheless, the use of forests in watershed management and restoration is still interesting, because it can contribute to regulate the water cycle during ordinary events, which occur more often than extreme ones, and also because forests proved efficient (Bruijnzeel, 2004; Calder et al., 2007) as a measure for soil erosion control. Hence, forests have a relevant role as sediment cycle regulators. This type of vegetal cover offers extraordinary conditions for the headwaters protection up to the timber line. Above this threshold, certain vegetal covers may exist with similar properties, such as the Andean pajonal (natural high-mountain pastureland) of the Andean Range above $3000 \mathrm{~m}$ asl on volcanic soils or andisols. The pajonal has a very high hygroscopic capacity, which disappears when this cover is disrupted. Therefore its protection is highly advisable.

Watershed management considers forests as a permanent cover, which exists as a result of specific climatic and soil conditions in certain locations. However, forests are composed of trees, which follow their own vital cycle. Consequently, when the watershed restoration implies the use of forests, either by reforestation or by natural regeneration, the required period to achieve their complete development needs to be taken into account. Mature stage is marked in particular by the highest efficiency of forests in soil protection and the lowest water consumption (Roberts et al., 2001; Vertessy et al., 2001; Iroumé and Hubert, 2002).

\section{Role of forests in different approaches to water cycle control and soil protection in areas affected by torrential events}

During the early $19^{\text {th }}$ century, large mountain areas in southern Europe underwent massive deforestation, causing major deterioration of their soils. This resulted in a significant risk for the inhabitants of catchments and for communication infrastructures, due to the threat of increasing peak flows, floods and channel aggradation processes caused by torrential events and avalanches. Accordingly, countries affected by these problems undertook the restoration of populated mountain areas, subsequently named correction of torrents or water and forest restoration. Andréassian (2004) pointed to Surrel (1841) as the most representative engineer, who established a methodology for mountain catchment correction in the French Alps. This author observed that it was essential to restore the catchment area, in order to ensure the efficacy of the hydraulic works carried out to correct the torrent itself. Therefore, in case a catchment was bare, reforestation was the first action to undertake. Thiery (1891) updated this methodology

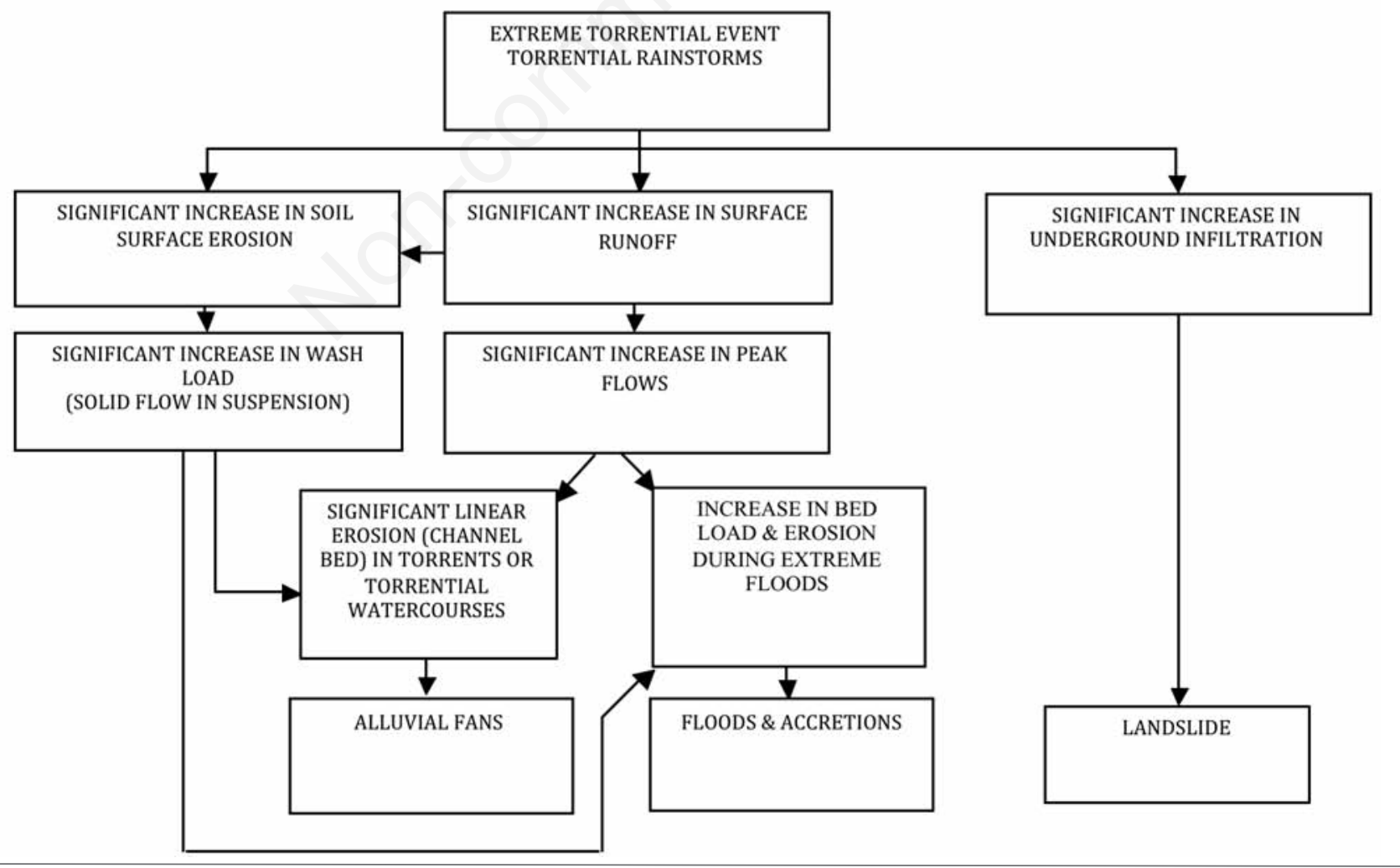

Figure 1. Effects of the water and sediment dynamics in the basin (translated from Mintegui Aguirre and Robredo Sánchez, 2008). 
and formalised some specific concepts regarding the correction of torrents and the flow forming streambed (equivalent to the bankfull flow associated with the flow rate of the ordinary torrential event) and the corresponding compensation slope linked to the above-mentioned flow rate. Additionally, also reforestation works of the catchment area were included in this approach. García Nájera (1943) developed an equation representing the movement of a quasi-monophasic flow for torrential streams, in order to establish a procedure to determine the above-mentioned compensation slope. Afterwards, Meunier (1991) gathered the last advances and his own experiences about the behaviour of mountain torrential streams and adapted them to be applied in the correcting works. Restored mountain catchments represent an important infrastructure with a significant economic impact. Such preterit effort is not considered or assessed in many cases, also neglecting the present necessity to maintain these infrastructures in a good conservation state. Water and forest restoration has also contributed to enhance the awareness about the importance of nature in the society. Likewise it has also highlighted the need for geomorphological criteria in the field of torrential stream reconstruction, including landscape adaptation, besides preserving the habitat of the torrential stream, especially in protected or touristic areas. These proposals were also put forward by other authors, e.g. Lenzi et al. (2000).

Mountain catchments also include populated areas with farmland and pastures, especially in the dominated areas. Therefore watershed management should ensure the protection and the productivity of those areas by undertaking water and forest restorations in the dominant areas, but also by planning works aimed to a direct protection in the populated areas and soil conservation measures on pastures and farmland to counter erosion processes. The orography of mountain catchments often imposed terrain systematization works by means of platforms to make them arable. These works were also done in ancient times in different cultures and in many regions and some of them still exist today.

As to soil conservation practices, the actions undertaken in United States of America after the enactment of the Law of Conservation of Soils (1935) represent a reference point. This law was approved as a consequence of the disastrous effects caused by the rapid transformation of grasslands and wild life surfaces into croplands, immediately after the I World War. Initially, this law focused on the stabilization and conservation of farmland and the improvement and conservation of pastures. At that time, the United States Department of Agriculture (USDA) soil conservation service was created (nowadays it is called USDA Natural Resources Conservation Service or USDA-NRCS), a land capability classification was established (Bennet, 1939) and the universal soil loss equation (USLE) was developed (Zingg, 1940; Musgrave, 1947; Wischmeier and Smith, 1978). A modification of the USLE equation led to the modified USLE (Williams, 1975) to estimate the basin sediment yield for single rainfall events. Afterwards, the revised USLE was proposed (Renard et al., 1991). Over the following decades, the USDA-NRCS integrated the soil conservation structures within the basin-scale hydrological models, blending the behavior of water and sediment cycles in the basin with the management and restoration measures. This made it possible to consider the behavior of nutrients in the watershed, as foreseen in the soil and water assessment tall model (Arnold et al., 1998; Arnold and Fohrer, 2005; Gassman et al., 2007). Originally the USDA soil conservation service (SCS) did not consider the mountain basins. However its subsequent research works contributed to the management of all the productive surfaces that can be found throughout the dominated areas, including mountain basins.

As to the Spanish experience, which has aspects that allow us to apply that experience to basins in Latin America, the Law of enhancement, promotion and reforestation of public woodlands (1877) can be seen as the first modern regulation on the use of forests for the control of the water and sediment dynamics. In the 1830's, the ownership of a large number of properties moved from the lords and the high clergy to private owners, who promoted a change in the use of land by turning woodlands into croplands. Consequently, this law was enacted to stop the cultivation of wide forest surfaces, given the relevant erosion problems resulting from the change in use of the land. Later, two new laws were enacted: Organization of reforestation works in the headwaters of watersheds in Spain (1888), and Creation of the water and forest services (1901). They established the new legal and administrative framework for the restoration of water and forests in mountain catchments, which required protection in the country. These restorations were planned and carried out, while similar works were being performed in other mountain areas in Europe.

By the mid- $20^{\text {th }}$ century, the surface of mountain watersheds undergoing water and forest restoration was significantly extended. This initiative was intended to face serious soil erosion problems in many mountainous regions in Spain, which were threatening the lifespan of the recently constructed water reservoirs. However, it was observed that, while these water and forest restoration works were efficient for the dominant areas of these increasingly larger basins, their impact on the corresponding dominated areas was almost negligible. These dominated areas, which represented an increasing proportion of the basin surfaces, mainly included crops, pastures and population settlements. Therefore, in these areas, it became necessary to apply soil conservation practices and adopt an environmental management approach. This is the context that led to the development of the water and land use management approach to watersheds as an alternative to the previous reconnaissance basin strategies to define the dominant areas where water and forest works should be planned and executed. In this context, the water and land use management approach became an established method to conduct preliminary studies to define the dominant areas, where water and forest works would be subsequently planned and executed. This approach makes it possible to define also the dominated areas, which can benefit from such works and require particular attention for the conservation of the productive soils and the management of the territory from the hydrological point of view (Aguiló, 1976; Mintegui Aguirre and López Unzu, 1990; López Cadenas de Llano et al., 1994). The Law of Water passed in 1985 focused on this aspect in article 40 , which states that water and forest restoration and soil conservation practices applied by the public administration must be specified in the basin hydrologic plans.

\section{Mountain watershed restoration and management projects resulting from the experience gained until today}

From the considerations above, we can infer that: i) the watershed is a study unit for the behavioural analysis of water and sediments cycles; ii) the protective effect of forests should be analysed at a watershed scale; iii) it is advisable to undertake basin management planning before beginning restoration works; and iv) both approaches to watershed management the watershed restoration were originally designed to enhance the security and the development of the population living within the watersheds.

The goals of the watershed management approach are: i) identification of the proper land uses for every surface in the watershed, according to its physical and biological characteristics, and the behaviour of its water and sediment cycles; ii) planning the necessary actions or adopting the corresponding regulations for the draining channels; and iii) proposal of appropriate measures to achieve the predetermined goal.

The watershed restoration approach involves the execution of the hydraulic works needed to restore the torrential streams and forestry activities to restore its catchment surface, following the criteria set 
out in the watershed management plan.

In summary, the main objectives of watershed management and, if needed, the subsequent water and forest restoration in the watershed are: i) protection of the population living in the basin, when water and sediment dynamics could cause damage due to torrential events, such as major precipitations or sudden snowmelt; and ii) regulation of water and sediments cycles within the watershed in every situation, either during torrential events or in the long periods between them, so that the population can optimize the use of water and soil resources, and achieve a sustainable development.

\section{Objective}

In our case report on three catchments located in mountainous areas of Latin America the goal was to ensure a balance between the productive areas and the natural areas where a permanent vegetal cover was to be reinstated. This was intended to provide greater stability to the water and sediment cycles, thus promoting sustainable development and at the same time greater protection from torrential events, or in other words establishing a water and land use management strategy for these catchments.

\section{Methodology}

In the past when a small scarcely populated mountain catchment was to undergo restoration (i.e. correction of the torrential course and rehabilitation of the drainage area), a preliminary reconnaissance was made in the catchment to verify its vulnerability to torrential events (normally through former documented episodes). In basins where the population is larger and has a more significant impact on land uses, a water and land use management plan is mandatory. This is what typically happens in mountainous regions in tropical areas of Latin America. The water and land use management approach to watersheds should be aimed to respond the concerns of the population, as well as to know in the most realistic way the effects that the water and forest restoration could cause.

The catchment management methodology described in this paper is based on the following three aspects: i) physical and biological characteristics of the catchment (Table 1); ii) the behavior of water and sediment cycles, especially the water and sediment dynamics produced by the intensification of both cycles; and iii) its socio-economic conditions. However there are two fundamental factors to take into account, namely the altitude and the slope, since they play a crucial role on the water and sediment dynamics triggered in the watershed. As to the altitude, the catchment area is divided into dominant and dominated areas. At the same time, also a map of slopes is produced and a reference threshold is identified to mark the boundary of the permanent vegetated cover (generally forests) to be maintained in order to control the water and sediment dynamics.

As to the slope, in water and land use management, it is essential to identify the level from which the soil must maintain a permanent vegetal cover to avoid hydraulic erosion (the most crucial component to trigger torrential geo-dynamism) and the slope where the forest is considered the only effective option to control such a processes. The slope must be $<24 \%$, and proved by trials carried out in experimental plots since the 1940's by the USDASCS, various agrologic soil classifications developed since then and particular experiences, such as those of García Nájera $(1954,1955)$ to control soil erosion in arable land, where soil conservation practices are applied. Above this percentage the soil would require significant structural measures, such as terracing, to control soil erosion. In the case of pastureland, these measures considered effective in protecting from hydraulic erosion up to a $30 \%$ slope and become less protective as the slope increases. These are recommendations proven experimentally. It is necessary to point out that these trials were carried out with runoff sheets, which occur in extraordinary
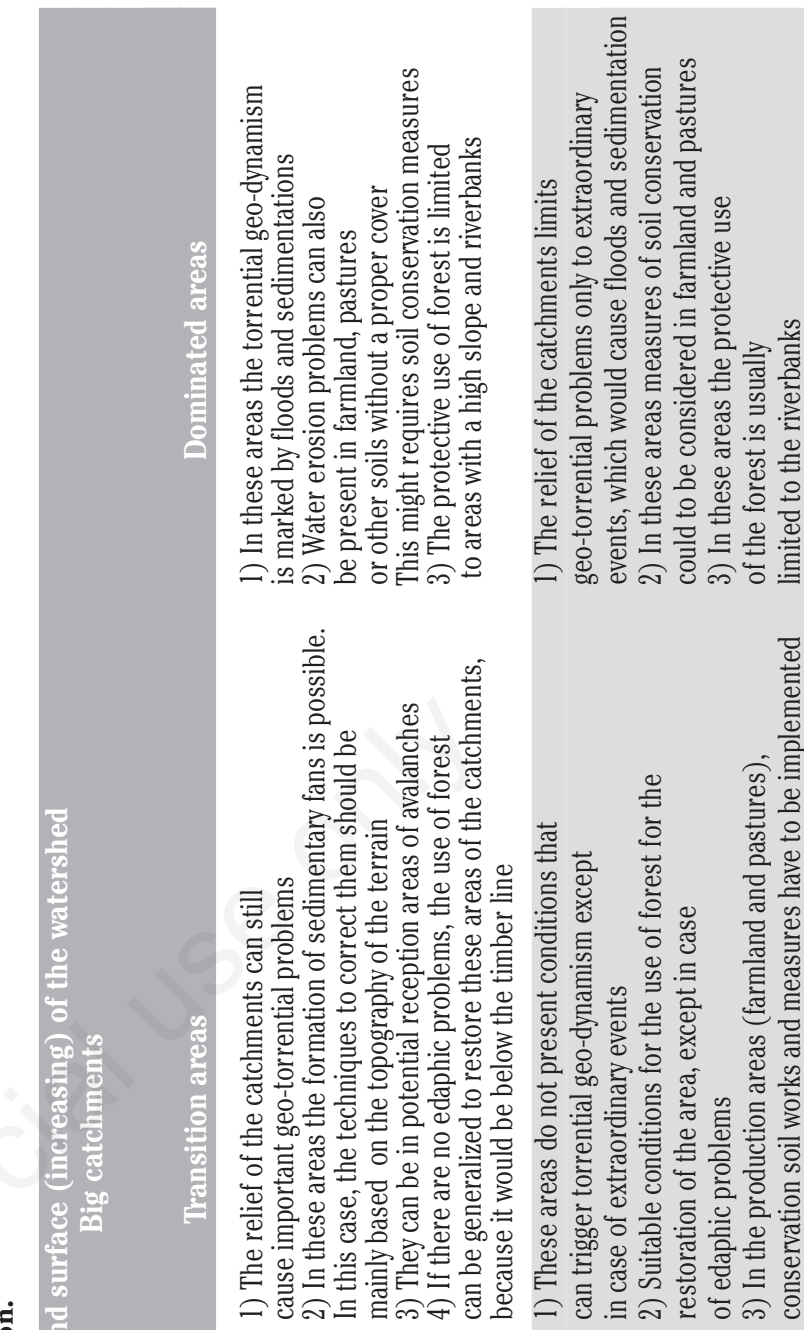

ป⿱艹
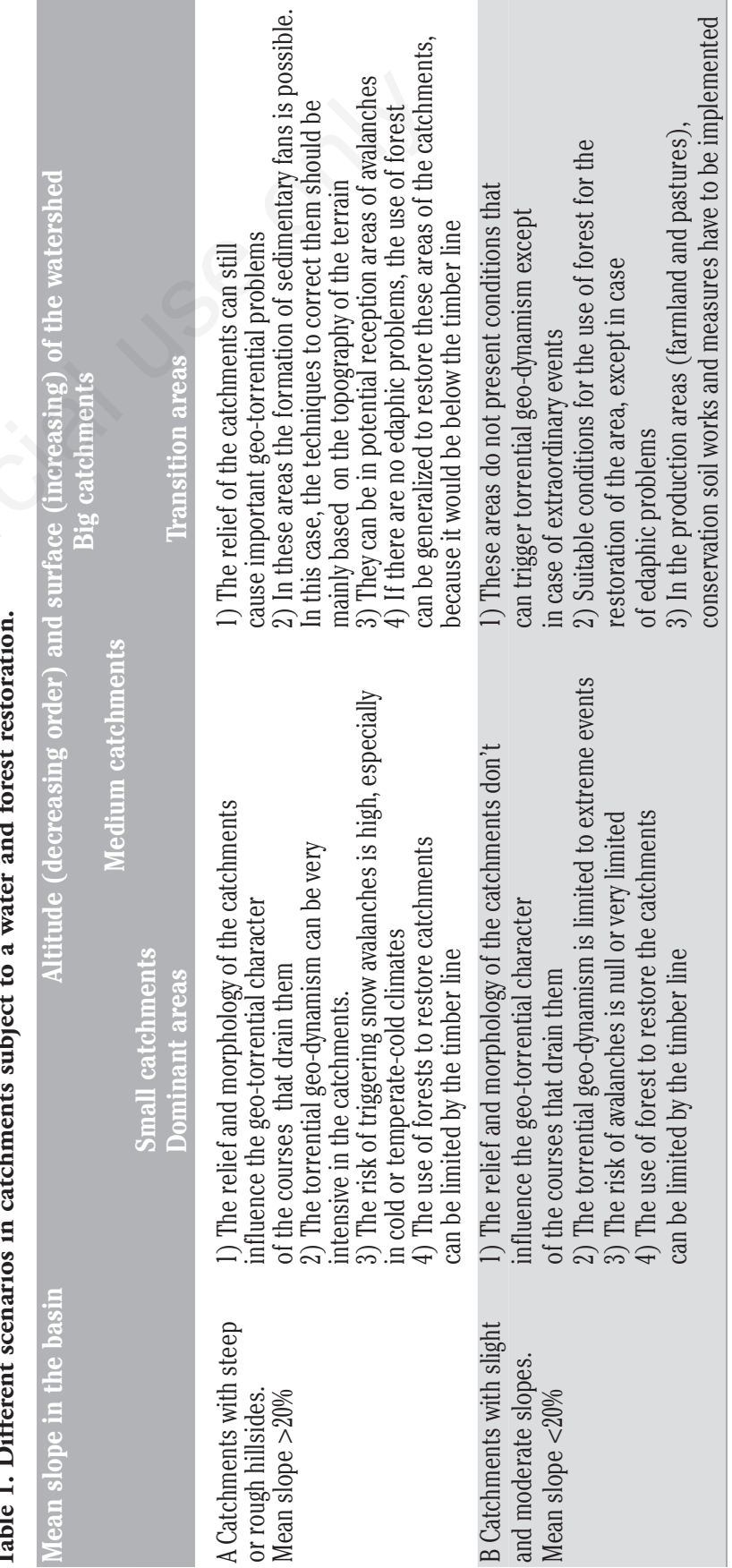
events, with a very low frequency. This is the reason why pastureland can often found in slopes steeper that $30 \%$ in a good state of preservation in many areas until an extraordinary event or an unfortunate anthropic action causes an initial gully, a ravine, or shallow slides. Experimental trial protocols are strict and identify these risks, but in the water and land use management of catchment areas also social-economic aspects need to be considerate. This requires an estimate of the likelihood of event recurrence and the implementation of rapid corrective actions in case of serious incipient erosions to rectify further generalised erosion problems in the catchment. Some mountain watersheds in the Andean, above $3000 \mathrm{~m}$ asl, are covered by pajonal, a natural high-mountain pastureland, seated on andosols. The pajonal has a very high hygroscopic capacity and it is the best soil protection for the mountain soils and for the downstream areas.

\section{Definition of a matrix with watershed scenarios where different management and restoration strategies can be applied according to their physical and biological features}

Table 1 shows a matrix of scenarios that can be found in a watershed according to the altitude and the slope. As to the slope (y axis), the matrix distinguishes watersheds with steep slope hillsides (A annotation) from watersheds with gentle to moderate hillsides (B annotation). In order to enhance this parameter, the mean slope of the basin is also taken into account. Therefore, when the average slope exceeds $20 \%$, situation A is considered, whereas when it does not, situation B becomes the reference. The altitude ( $\mathrm{x}$ axis) defines the dominant, transition and dominated areas in the watershed. These areas are clearly defined in large watersheds, whereas the dominant and transition areas predominate in midsize watersheds with very limited dominated areas. Small basins usually are drained by small torrential streams, so the transition and the dominated areas, corresponding to the gorge and to the sedimentary fan respectively, present a relatively small surface compared with the dominant area.

This matrix can specify in each of the six scenarios: i) the intensity of the potential water and sediment dynamics; ii) the avalanche risk; and iii) the capacity of forests to restore the watershed. The next step is to define the guidelines to correct problems associated with the water and sediment dynamics for each scenario and to suggest the most appropriate technique, in case of: i) correction of torrential streams; ii) defense against avalanche risk; iii) hillsides restoration; iv) landslide correction; and v) land use restrictions depending on slope and altitude (Mintegui Aguirre and Robredo Sánchez, 2008).

\section{Definition of a matrix with impacts caused by different torrential events in the watershed}

The management and restoration of watersheds need to take into account the behavior over time associated with all kinds of meteorological events. Hence, it is necessary to establish a minimum period for the restoration measures to be consolidated.

The evidence-based policy for integrated control of forested river catchments in extreme rainfall and snowmelt (EPIC FORCE) project incorporates this notion into a matrix of impacts (Table 2). The y axis indicates the different kind of torrential events, whereas the $\mathrm{x}$ axis includes: i) the effects caused by torrential events; ii) the way in which research can contribute to specify such impacts; iii) the need to establish the management and restoration criteria based on scientifically verifiable evidence (main objective of the EPIC FORCE project); and iv) the adoption of appropriate management and restoration techniques with objectives based on the behaviour of watersheds in different torrential events and the available experience in this field.

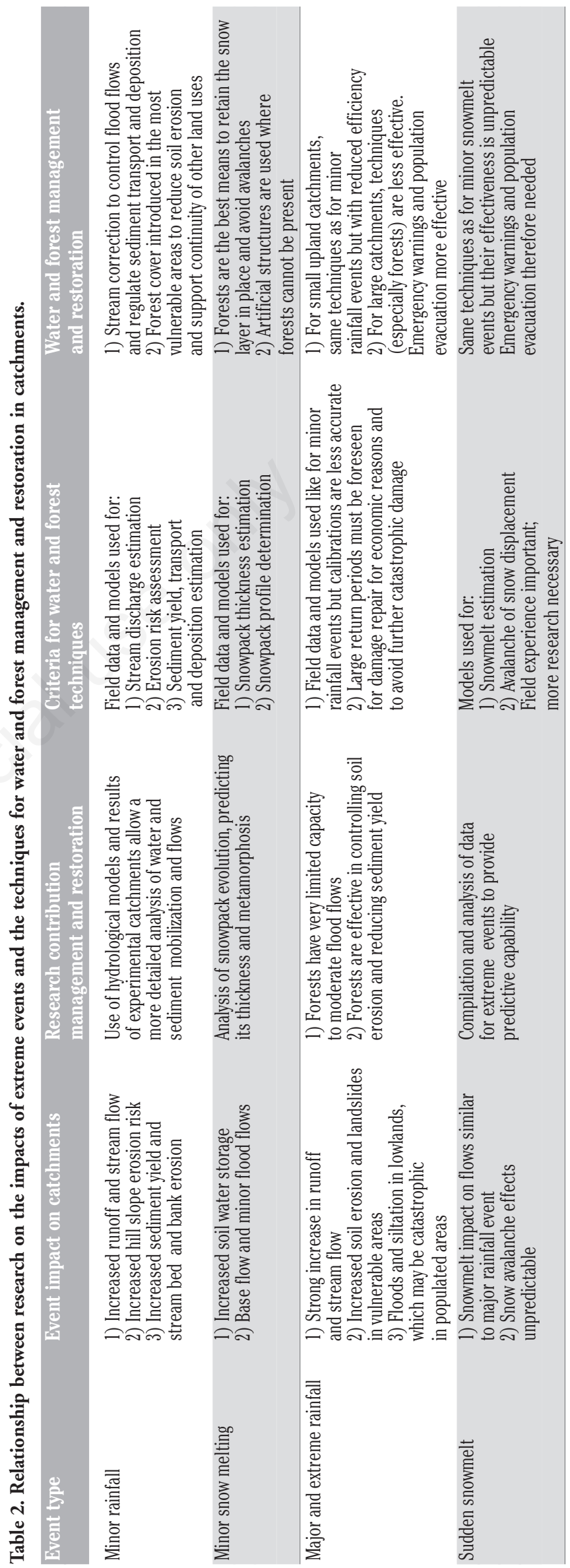




\section{Estimated benefits from watershed restoration}

Major rainfall events are often associated with an occurrence probability or recurrence interval. Not only does the EPIC FORCE project highlight this aspect, but it also relates such events to the specific water and sediment dynamics that are triggered in each case, identifying and classifying these effects into four categories (Figure 2): minor damages, major damages, disaster damages and catastrophic damages (Sarandón et al., 2007). In Figure 2, the magnitude of the rainfall events is represented on the y axis as recurrence interval, whereas the physical state of the basin is indicated on the $\mathrm{x}$ axis. The plot is broken down in four areas, representing the four categories divided by lines A, B and C (Bathurst et al., 2010). The three vertical lines represent the watershed state before (on the left) and after (in the middle of the plot) the restoration works and after these works are consolidated (on the right). The benefits resulting from the restoration coincide with the intersection of the three vertical lines with lines $\mathrm{A}, \mathrm{B}$ and $\mathrm{C}$.

\section{Surface classification in the watershed using the present methodology}

Considering all the factors that define the different areas of the watershed, both the main ones, such as altitude and slope, and those related to the behaviour of each surface, the management strategy distinguishes between: i) protection areas, mainly present in the dominant areas, where the use of soil is limited in order to prevent the beginning of water and sediment dynamics processes; ii) production areas, where croplands and pastures are predominant, usually applying soil conservation practices; iii) restricted production areas, where the production is maintained due to socio-economic constraints, but measures for soil erosion control are required, such as bench terracing in case of arable land on steep slopes, or the change in land use from pastures to secondary forests, where continuous shallow landslides are present.

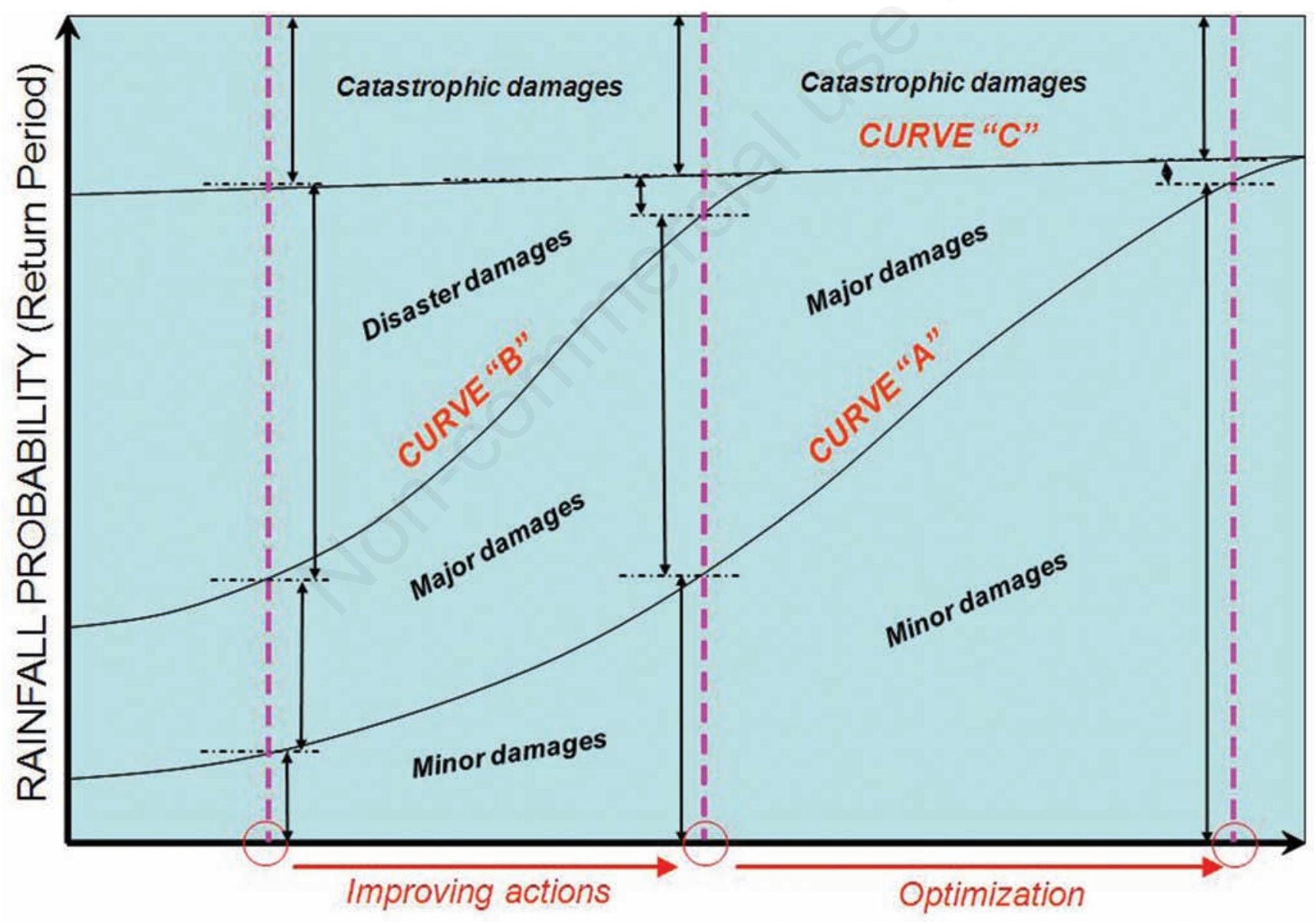

CATCHMENT FEATURES

Figure 2. Chart of the benefits resulting from water and forest restoration in the basin due to the enhancement of its physical and biological conditions. The three vertical lines represent: $i$ ) previous state of the basin before the restoration works (left), and ii) the subsequent physical state of watershed (center and right) after the execution of the works and after effects become consolidated. The benefits from the restoration works are indicated by the differences in segments between intersections of the three lines with curves A, B and C. 


\section{Results}

\section{Water and land use management in three small mountain watersheds in Latin America}

The catchment areas studied were the Pejibaye River (Costa Rica) and Guabalcón river (Ecuador) as examples of medium-high mountains torrential basins, and the Buena Esperanza stream (Argentina) situated in the Andean-Patagonian region. The behavior of the water and sediment cycles in these catchment areas was simulated using the SHETRAN Modelling System (Ewen et al., 2000) during the development of EPIC FORCE project (Bathurst et al., 2011a, 2011b). At the same time the team from the Universidad Politécnica de Madrid carried out several field surveys on the basin to develop the water and land use management approach (Mintegui Aguirre and Robredo Sánchez, 2008).

\section{Pejibaye River basin (Costa Rica)}

The Pejibaye River basin was analyzed down to the confluence with the Águilas River. The watershed has an area of $131 \mathrm{~km}^{2}$ and is in the canton of Pérez Zeledón, in south-eastern Costa Rica, between $83^{\circ} 33^{\prime}$ and $83^{\circ} 42^{\prime} \mathrm{W}$ longitude and between $9^{\circ} 9^{\prime}$ and $9^{\circ} 13^{\prime} \mathrm{N}$ latitude. The Pejibaye River basin is a mid-size rugged watershed with an elevation ranging from $368 \mathrm{~m}$ asl to $1221 \mathrm{~m}$ asl. Steep slopes are present throughout the watershed (27\% on average), which has an oval-circular morphology. The basin drains towards the Pacific Ocean. From the hydrological and environmental point of view, it is a typical tropical midmountain watershed, with a very marked alternation of rainy and dry seasons, and a precipitation module above $2000 \mathrm{~mm}$. Generally, it has deep, acid and well drained soils, with a fine texture and low permeability (Ustic Happlohumutl) to the north, and a moderately fine texture and shallower and more permeable soils (Ustic Dystropets) to the south. The estimated mean annual temperature of the basin is $22^{\circ} \mathrm{C}$ and can vary from a minimum of $11^{\circ} \mathrm{C}$ to a maximum of $29^{\circ} \mathrm{C}$.

Until 1940 the basin was covered by wet tropical forests. At that time, large forested surfaces were cleared to transform them into farmland. Nowadays, $50 \%$ of the watershed is dedicated to crops and is divided into: i) shadow coffee plantations (usually in bench terraces with small trees providing shadow, and soil conservation practices); ii) rotation of corn and bean crops (also with soil conservation practices); and iii) other crops, such as tiquizque or ginger combined with corn. Another $45 \%$ of the watershed is dedicated to permanent pastures for extensive cattle breeding. No soil conservation practice is applied in these extensive pastures, locally called potreros, so an important part of them show signs of degradation. The remaining $5 \%$ is covered by secondary forests.

The basin maintains a very high bio-climatic capacity, which allows the return of most arable land and pastures to secondary tropical forest by simply abandoning the current uses. This potential could be an advantage for restoration works in the basin. If we compare the reforestation works made to restore and regenerate the soil in mountain basins in southern Europe in $19^{\text {th }}$ century with the case of Pejibaye, we can see that a natural, efficient and cheap alternative exists when forests are being introduces after a restoration plan. Secondary forests have a hydrological behavior similar to primary forests, although they are different in terms of biodiversity.

The catchment population is estimated in 15,000 inhabitants. All the age groups are represented. The population is spread over the whole catchment area in 24 small villages. The main activities are agriculture and cattle breeding. Arable land and pastures can be found at different altitudes and slopes over the whole watershed, sometimes with an uncertain viability in the medium and long term. The most important village is Pejibaye, which is in the lower part of the basin, close to the river bearing the same name.

\section{Main aspects of the present water and sediment dynamics}

The main problem of the basin, accentuated by the rugged orography and frequent torrential precipitations, is the vulnerability of the soils to water erosion, which threatens the sustainability of land development over time. Steepest hillsides, especially those with pastures in the dominant areas, show often shallow landslides coinciding with strong torrential precipitations in the wet season. The objective of the water and land use management strategy is to enhance the management of the natural resources, especially the soil, as well as to plan the necessary water and forest restoration measures to ensure the maintenance of the population in the medium and long term. The following criteria were used:

- Areas at or above $700 \mathrm{~m}$ asl were defined as dominant areas. Here the recommendation is to prioritise practices for soil erosion control.

- In the case of severe water erosion signs, the critical slope threshold from which the secondary forest has to be reintroduced is $60 \%$; especially where shallow landslides are present in pastures. This limit could be considered excessive, taking into account the results of many experimental studies, which set it at $30 \%$. But it is necessary to point out that these studies are based on a laminar run-off corresponding to major events (García Nájera, 1954, 1955), which have a low frequency. In practice, pastures in good state of conservation on slopes over $30 \%$ may be found in many geographic areas, until an extraordinary torrential event or an inadequate human action causes significant fissures in the terrain, thus generating gully erosion, ravines or shallow landslides. However, also socio-economic aspects need to be considered in watershed management, even though the protocol used in the above-mentioned studies includes that risk. Therefore it is necessary to estimate the occurrence probability of torrential events, and also to correct quickly the incipient erosions, in order to avoid more serious problems of widespread erosion.

- The techniques proposed to protect the soil in areas affected by water erosion are focused on: i) the recovery of secondary forest; ii) the execution of systematization works on the terrain (platforms or benches), if slopes exceed 30\%; and iii) the application of soil conservations measures (terraces) and soil conservation practices (contour and strip cultivation) when the slope is below $30 \%$. It was also recommended to complete the systematized terrains with soil conservation practices.

- Protection areas, where secondary forest is necessary, are defined as terrains with a slope greater than $60 \%$ or even less when the place shows serious soil erosion signs, especially in the dominant areas. Production areas have a slope below $30 \%$ and can be anywhere in the basin. In these areas the soil conservation works defined by the UDA-SCS are recommended. Restricted production areas include terrains with slope between 30 and $60 \%$, where most of the shadow coffee plantations and extensive livestock pastures are.

- For the maintenance of the forest riverside in the drainage channels of the basin, the environmental laws of Costa Rica were considered. Its criteria were used to develop the water and land use management guidelines for the Pejibaye River basin, shown in Table 3.

\section{Guabalcón River basin (Ecuador)}

The Guabalcón river basin is in the western Andean mountain range at the centre of Ecuador, between $78^{\circ} 58^{\prime} 10^{\prime \prime}$ and $78^{\circ} 53^{\prime} 05^{\prime \prime}$ W longitude, and $2^{\circ} 24^{\prime} 02^{\prime \prime}$ and $2^{\circ} 15^{\prime} 54^{\prime \prime} \mathrm{S}$ latitude. It is in the Chunchi canton in the province of Chimborazo, and includes the parishes of Compud and Llagos. The watershed has a surface of $65.83 \mathrm{~km}^{2}$, a steep orography with a mean slope of $56 \%$ and an elevation range between 
$4420 \mathrm{~m}$ asl and $1370 \mathrm{~m}$ asl. The mean altitude is $2000 \mathrm{~m}$ asl. The morphology is oval-elongated with a Gravelius index of 1.44. The basin drains towards the Pacific Ocean. From the hydrological and environmental point of view, it is a typical high mountain tropical basin. The precipitation module is $700 \mathrm{~mm}$ at lower altitudes and $1000 \mathrm{~mm}$ above $2800 \mathrm{~m}$ asl, with a clearly marked alternation of wet and dry seasons. Three types of soils can be found according to the altitude distribution. At higher altitudes, soils composed of volcanic ashes or andisols predominate and account for $9 \%$ of the surface. The rest of the area shows an alternation of cambisols (50\%) and leptosols (41\%). The mean temperature in the central area, where the most significant agricultural activities take place, is $15^{\circ} \mathrm{C}$, ranging from a minimum of $11^{\circ} \mathrm{C}$ to a maximum of $27^{\circ} \mathrm{C}$.

The vegetation of the basin can be grouped into five bands, as the altitude decreases: i) typical extensive grasslands in the high plateau (pajonal típico del altiplano) over andisols above $3600 \mathrm{~m}$ asl, which represents $14.8 \%$ of the basin; ii) evergreen vegetation (chaparro) mixed with pajonal, over $2800 \mathrm{~m}$ asl, covering $17.2 \%$ of the surface; iii) pasture and evergreen vegetation (chaparro) in a populated area with irrigated pastures, which occupies $42.2 \%$ of the catchment area; iv) croplands and pastures, below $2000 \mathrm{~m}$ asl, which account for $18.6 \%$ of the catchment area and presents some unstable hillsides with a very high landslide risk; and v) bush and croplands, at the lower and dryer zone of the watershed, representing $7.2 \%$ of the whole catchment area.

The population living in the basin is about 1700 inhabitants, who live on a subsistence economy. In the dominated area, in the farmland and pastures, the population grows horticultural products and, to a lesser extent, breeds ovine livestock. The population settled in the highlands, where the grassland and evergreen vegetation are, mainly raises ovine livestock in a context of small-scale agriculture. It is important to note the crops are all grown on irrigated land.

The Guabalcón River basin is a typical torrential mountain watershed with a catchment area, a gorge and an alluvial fan. It is potentially very vulnerable to water and sediment dynamics. The catchment area (75\% of the basin) and the gorge (4 km long and a high slope) are well defined. On the contrary, the alluvial fan is very negligible, since the steep slope of the Guabalcón river favors the evacuation of the debris from the channel directly towards the Chanchán river, which can absorb its sediment load from the Guabalcón river, transporting it downstream together with its own sediment load.

\section{Main aspects of the present water and sediment dynamics}

The main objective of the water and land use management plan for the Guabalcón river basin is to retain the population who lives there, trying to enhance the living conditions by using their natural resources, especially water and soil. The aim is to ensure the conservation of these resources in the medium and long term, adopting the required measures to avoid their degradation in major torrential events, and a potential increased risk for the population.

The proposed water and land use management approach considers a threshold of $2000 \mathrm{~m}$ asl in order to differentiate the dominant areas from the dominated areas. The area above $2800 \mathrm{~m}$ asl is defined as protection area, where the conservation of the existing vegetation is recommended. The areas between 2000 and $2800 \mathrm{~m}$ asl, with a slope exceeding $60 \%$, or the areas with evidence of severe erosion below such slope are defined as protection areas. The remaining surface is defined as restricted production area. In the dominated areas, human settlements were forbidden in some lands in the northeast of the basin due to the rotational landslide risk. The remaining surface was defined as protection area in case of a slope greater than $60 \%$, restricted production area when the slope is between 30 and 60\%, and production areas with a slope below $30 \%$. The soil conservation measures proposed by USDA-SCS are recommended for every productive area. These criteria

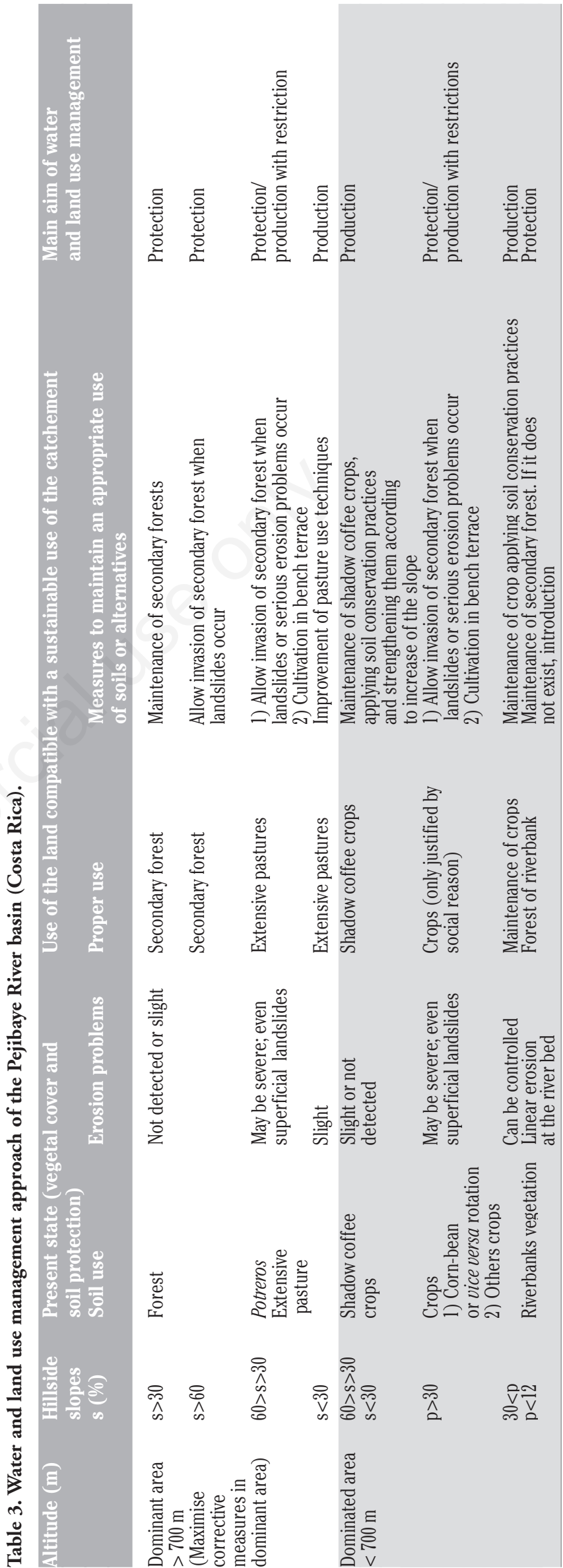


were taken into account to propose a water and land use management approach of the Guabalcón river basin, summarised in Table 4.

\section{Buena Esperanza stream basin (Tierra del Fuego, Argentina)}

The Buena Esperanza stream basin is in the Fueguinean mountain range. With a surface of $14.6 \mathrm{~km}^{2}$, it is north of the city of Ushuaia, between $68^{\circ} 19^{\prime} 06^{\prime \prime}$ and $68^{\circ} 25^{\prime} 00^{\prime \prime}$ W longitude, and $54^{\circ} 46^{\prime} 28^{\prime \prime}$ and $54^{\circ} 49^{\prime} 12$ " S latitude. Its elevation is maximum $1266 \mathrm{~m}$ asl, and minimum $114 \mathrm{~m}$ asl. It is marked by a rugged orography, but it is protected against the prevailing winds, therefore calms are more frequent than in the rest of the Tierra del Fuego island. It presents an oval-rectangular morphology, with a well-defined drainage network. The basin represents the dominant area of the westward expansion of the city of Ushuaia, being this last the dominated area. The upper zone of the drainage basin has glacial characteristics and the lower reach forms the northern limit of the city of Ushuaia. Soils are mainly shallow and their development decrease as the altitude increases. Climate is a decisive factor in the basin. Mean temperature at sea level is $5.5^{\circ} \mathrm{C}$, decreasing towards the inland area according to the altitudinal gradient. Annual precipitation in the Beagle coast is $520 \mathrm{~mm}$, reaching 1300 $\mathrm{mm}$ on the inner summits due to the orographic effect. It presents a snow-glacial hydrological regime. Runoff is controlled by the seasonal snow, the storage in the detritus deposits of the mountain range and the glacier supplies. Headwaters reach $1400 \mathrm{~m}$ asl and they present small glaciers that contribute to the runoff of the Buena Esperanza stream, which has a flow rate module of $300 \mathrm{~L} \cdot \mathrm{s}^{-1}$, and is one of the sources of drinking water for the city. Its water is hypotonic, slightly carbonated and with great transparency. Its $\mathrm{pH}$ varies around 7 and the content in iron is moderately high. Nevertheless, in the medium and low reaches of the main channel, there are evidences of coliform contamination.

These climatic and soil characteristics limit the forest development in the watershed, which takes up to $44 \%$ of the whole catchment area. The rest of the surface is divided into bare soils (52.4\%) and urban areas (3.6\%). The Martial glacier occupies the higher elevation area of the basin and the vegetation is reduced to a tundra at its lower limit. The mid-elevation area, below $600 \mathrm{~m}$ asl $( \pm 100 \mathrm{~m}$ depending on the exposure of the hillside and the distance from the sea) is occupied by the perennial Nothofagus betuloides (guindo or coihue of Magallanes), while the lower level has deciduous Nothofagus pumilio (lenga) and Nothofagus antartica (ñire) Puigdefabregas et al. (1988), Roig (1998), which account for $35 \%$ of the catchment area, but their strategic position enables them to buffer the water and sediment dynamics. The Sphagnum covering the peatlands at the threshold of the moraine, between $250 \mathrm{~m}$ and $300 \mathrm{~m}$ asl, represents an important element with a high moisture retention capacity. They occupy $3.2 \%$ of the catchment area. No important agricultural activities are present at the catchment area. Nevertheless, the city has a significant urban and touristic impact affecting the land use in the mid and low elevations, which are very vulnerable to anthropic alterations.

\section{Main aspects of the present water and sediments dynamics}

The proposed management approach is intended to combine a continuous land use for the economic development with the conservation of the basin's natural resources that are essential for its protection, and also to maintain a sustainable use of the water yield of the basin. In this context, the Nothofagus forests present at mid-elevations are an essential element, because they influence the intensity of geo-torrential processes that snow or rain events can produce in the Buena Esperanza basin. They have a special protective effect over the domi- nated area, where the city of Ushuaia is located, against possible floods or sedimentation. The importance of these forests may be assessed on the basis of the costs resulting from the execution and maintenance of an infrastructure with the same protecting functions and benefits that these forests have for the city of Ushuaia. In addition, these forests have a significant esthetic value for the city. The protective effect that the Nothofagus forests have in Ushuaia is similar to that of the reforestations made in the past in wide regions of the Alps. Nowadays, those areas host important centres for winter sports. Peatlands and detritus deposits also contribute to the hydrological regulation of the basin.

Lastly Patagonian forests are characterised by an abundant presence of woody debris on the ground (tree trunks, thick branches, etc.). These conditions can also be observed in the Buena Esperanza basin. In forests at warmer latitudes such accumulation of woody debris could be a significant source of pathogens or insects, and have a relevant fire load, being highly combustible. However the low temperatures of southern regions attenuate significantly or almost eliminate such risks. Another potential severe risk is associated with the accumulation of wood debris on the banks and the channel of the Andean torrential courses. In case of flood, water flows would transport large wood deposits downstream, thus causing possible blockages in the river channel. The collapse of such blockages can provoke flash floods of water and sediment downstream. In case of presence of elements to protect in the trajectory damages would be as important as the blockage. The transport of woody debris in the Buena Esperanza basin was studied by the University of Padua in the EPIC FORCE project (Mao et al., 2008a, 2008b; Comiti et al., 2008).

In the Buena Esperanza stream, ordinary floods transport woody debris together with the bedload sediments of the stream. Usually, this fills up the little deposit next to the city water system input, which is upstream to the northern part of the city, which is subsequently emptied, due to its small size. Nevertheless, in a long term planning of the basin, the possibility for the woody debris going downstream and reaching the urban area of the city during extreme events should be considered.

Moreover, the Buena Esperanza stream basin can be considered representative of the small mountain basins affected by anthropic activities in the Andean-Patagonian region. Therefore, the conclusions derived from the proposed water and forest management approach for the Buena Esperanza stream basin (Table 5) could be extended to a wider area. Unlike the other two case studies, here the only objective is to protect the city of Ushuaia, the availability of water and its extraordinary natural heritage.

\section{Discussion}

The EPIC FORCE Project is intended to explain scientifically the influence of forests in the lamination of peak flows and extreme floods. The results show that forests practically have no influence in such situations, especially in large basins affected by such events. In this respect, the only recommendation to suggest would be limited to determine the flooding areas associated with the different recurrence periods, and to propose monitoring, rescue and evacuation measures for the people trapped in disaster situations. It is to be noted that neither the forest nor its absence have a direct relationship with the risk involving infrastructures and houses in flooding areas, since the threat is essentially associated with their location.

However, the catchments are more frequently affected by minor torrential events, in which forests influence markedly the runoff and flood 


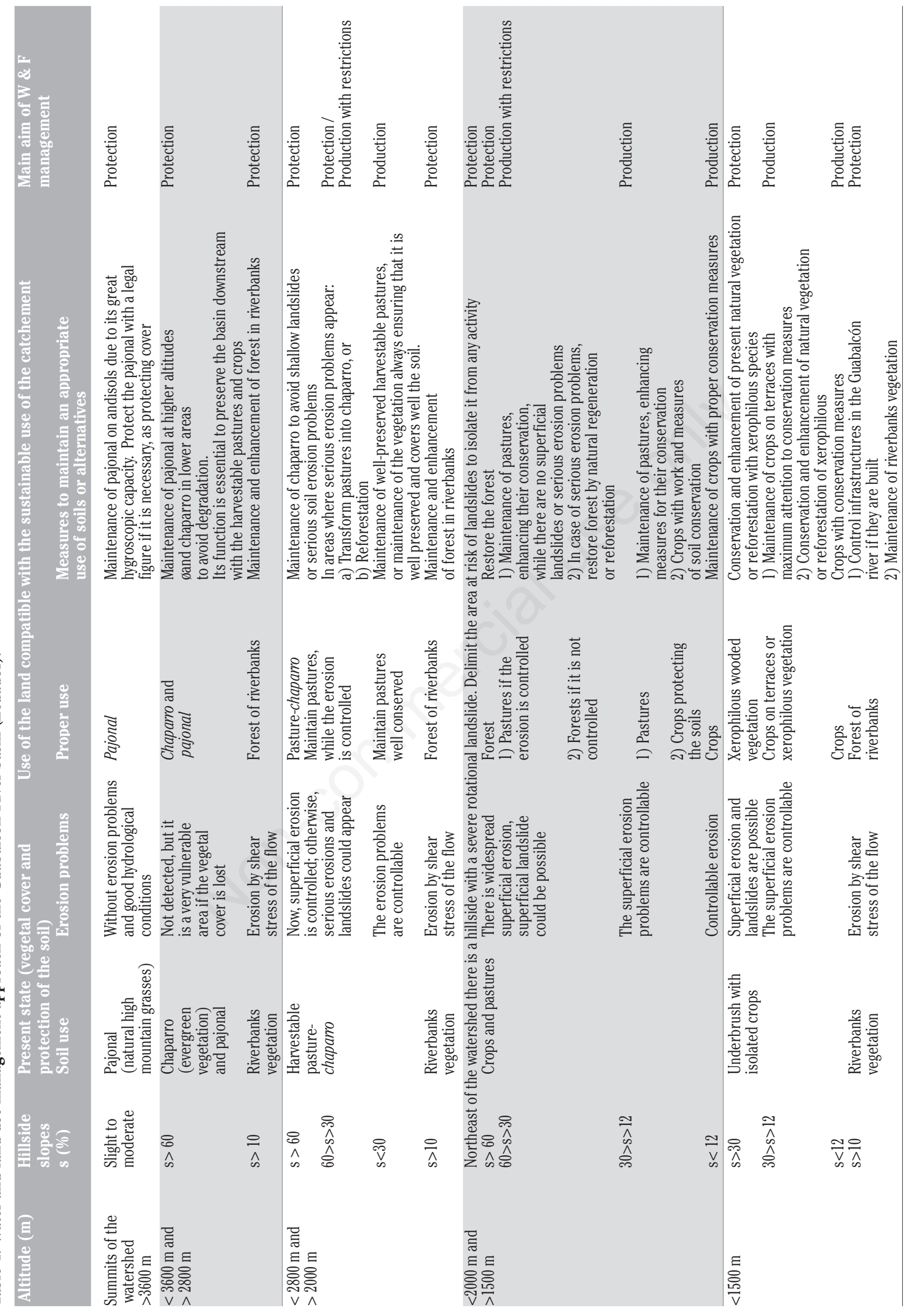




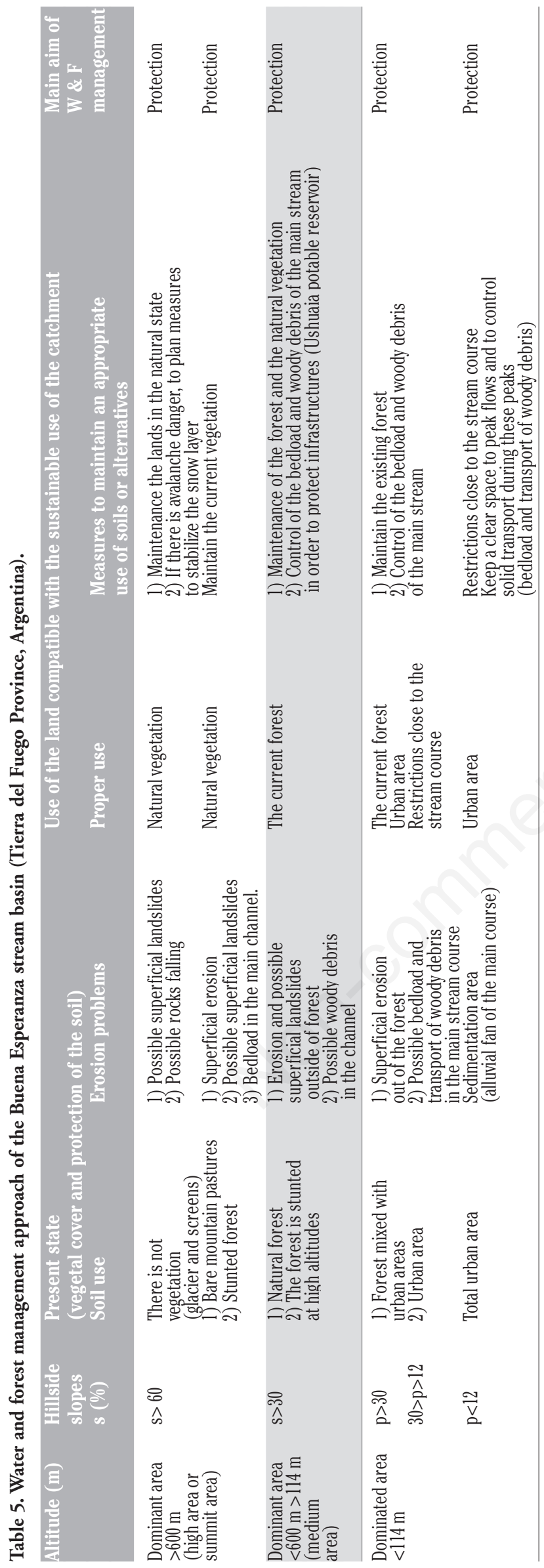

generation. Moreover, forests offer a protective cover on the soils from water erosion, and contribute to laminate the sediments cycle. Bathurst et al. (2010) proved scientifically this aspect, in relation to the EPIC FORCE project, and has been formally set up in this text. On the other hand, basin management and restoration activities need to be planned according to a wide range of possible meteorological events and their potential consequences, not only on the basis of extreme events. These are the criteria adopted to develop the section entitled Strategies for water and forest resources management in EPIC FORCE project. For the development of this project, not only were the most recent scientific results considered, but also the available knowledge on management and restoration of drainage basins and on the protection of farmland from water erosion.

\section{Conclusions}

The assumption according to which forests have practically no incidence in the formation of peak flows and floods, when extreme rainfall events occur in large basins, and these events extend on the time, is totally compatible with the statement on the necessity of basin's management planning and water and forest restoration, in order to control the water and sediment cycles and avoid serious erosive problems.

The probability of occurrence of extreme rainfall events is low and its recurrence period is long, thus enabling recovery of the basin from their effects along with the catchment morphological development. Nevertheless, a continuous misuse of water and soil resources in the basin, formally associated with an alteration of the water and sediment cycles, produces a gradual and unpredictable degradation of the catchment area, along with a progressive impoverishment of the inhabitants.

Forests play a buffering role in the water and sediment cycles in the drainage basin; therefore their presence is necessary in the more vulnerable portions of the catchment area, in order to control the water and sediment dynamics.

\section{References}

Aguiló Bonnín J. 1976. Evaluación de inversiones en la ordenación agro-hidrológica de cuencas. Publicaciones del Ministerio de Agricultura, Madrid, Spain.

Andréassian V. 2004. Waters and forests: from historical controversy to scientific debate. J. Hydrol. 291:1-27.

Arnold J.G., Fohrer N. 2005. SWAT2000: Current capabilities and research opportunities in applied watershed modeling. Hydrol. Proc. 19:563-72.

Arnold J.G., Srinivasin R., Muttiah R.S., Williams J.R. 1998. Large area hydrologic modeling and assessment: part I. Model development. JAWRA 34:73-89.

Bathurst J.C., Amezaga J., Cisneros F., Gaviño Novillo M., Iroumé A., Lenzi M.A., Mintegui Aguirre J., Miranda M., Urciuolo A., 2010. Forests and floods in Latin America: science, management, policy and the EPIC FORCE Project. Water Int. 35:114-31.

Bathurst J.C., Birkinshaw S.J., Cisneros F., Fallas J., Iroumé A., Iturraspe R., Gaviño Novillo M., Urciuolo A., Alvarado A., Coello C., Huber A., Miranda M., Ramirez M., Sarandon R. 2011b. Forests impact of floods due to extreme rainfall and snowmelt in four Latin America environments 2: Model analysis. J. Hydrol. 400:292-304.

Bathurst J.C., Iroumé A., Cisneros F., Fallas J., Iturraspe R., Gaviño Novillo M., Urciuolo A., de Bièvre B., Guerrero Borges V., Coello C., 
Cisneros P., Gayoso J., Miranda M., Ramirez M. 2011a. Forest impact on floods due to extreme rainfall and snowmelt in four Latin American environments 1: Field data analysis. J. Hydrol. 400:281-91. Bennet H.H. 1939. Soil conservation. Mac Graw-Hill Co., New York, USA. Bruijnzeel L.A. 2004. Hydrological functions of tropical forests: not seeing the soil for the trees? Agric. Ecosyst. Environ. 104:185-228.

Calder I.R., Aylward B. 2006. Forest and floods: moving to evidence based approach to watershed and integrated flood management. Water Int. 31:87-99.

Calder I.R., Hofer T., Vermont S., Warren P. 2007. Towards a new understanding of forest and water. Unasylva 229:3-10.

Comiti F., Andreoli A., Mao L., Lenzi M.A. 2008. Wood storage in three mountain streams of the Southern Andes and its hydro-morphological effects. Earth Surf. Proc. Landforms 33:244-62.

Ewen J., Parkin G., O'Connell P.E. 2000. SHETRAN: distributed river basin flow and transport modeling system. Proc. Am. Soc. Civil Engineering. J. Hydrol. Engine. 5:250-8.

García Nájera J.M. 1943. Principios de hidráulica torrencial y sus aplicaciones a la corrección de torrentes. Instituto Forestal de Investigaciones y Experiencias, Madrid, Spain.

García Nájera J.M. 1954. Pendientes máximas admisibles en las tierras de cultivo y cálculo de las terrazas intermitentes con desagüe para la conservación del suelo (banquetas de infiltración). Instituto Forestal de Investigaciones y Experiencias, Madrid, Spain, p 29.

García Nájera J.M. 1955. El bosque, el agua y la conservación del suelo, pendiente máxima admisible en los pastizales. Instituto Forestal de Investigaciones y Experiencias, Madrid, Spain, p 7.

Gassman P.W., Reyes M.R., Green C.H., Arnold J.G. 2007. The soil and water assessment tool: historical development, applications and future research direction. Soil Water Divis. ASABE 50:1211-50.

Iroumé A., Hubert A. 2002. Comparison of interception losses in a broaleaved native forest and a Pseudotsuga menziessi plantation. Hydrol. Proc. 16:2347-61.

Lenzi M.A., D’Agostino V., Sonda D. 2000. Ricostruzione morfologica e recupero ambientale dei torrenti. Bios, Milano, Italy.

López Cadenas de Llano F., Fernández Tomás G., Segura Graiño J., Almansa López R., Alonso Fernández-Coppel M.C., Baratech Torres F., Bartolomé Nebreda J.C., Cocero Alonso A., Delgado Sánchez J.C., Del Pozo Manrique M., González Romero A., Montalvo Montalvo J., Nicolás Rodríguez J., Rábade Blanco J.M., Tejera Gimeno R., Tejero González L., Torrente Poveda E., TournéWhyte M. 1994. Restauración hidrológico-forestal de cuencas y control de la erosión.Tragsa, Tragsatec \& Ediciones Mundi Prensa, Madrid, Spain.

Mao L., Andreoli A., Comiti F., Lenzi M.A. 2008a. Geomorphic effects of large wood jams on a sub-Antarctic mountain stream. River Res. Appl. 24:249-66.
Mao L., Burns S., Comiti F., Andreoli A., Urciuolo A., Gaviño-Novillo M., Iturraspe R., Lenzi M.A. 2008b. Acumulaciones de detritos leñosos en un cauce de montaña de Tierra del Fuego: análisis de la movilidad y de los efectos hidromorfológicos. Bosque 29:197-211.

Meunier M. 1991. Éléments d hydraulique torrentielle. Etudes Montagne. CEMAGREF Groupement de Grenoble, France.

Mintegui Aguirre J.A., López Unzu F. 1990. La ordenación agrohidrológica en la planificación. Servicio de Publicaciones del Gobierno Vasco, Vitoria, Spain.

Mintegui Aguirre J.A., Robredo Sánchez J.C. 2008. Estrategias para el control de los fenómenos torrenciales y la ordenación sustentable de las aguas, suelos y bosques en cuencas de montaña. UNESCO PHI-LAC 13, Montevideo, Uruguay.

Musgrave G.W. 1947. The quantitative evaluation of factors in water erosion: a first approximation. J. Soil Water Conserv. 3:133-8.

Puigdefábregas J., Del Barrio G., Iturraspe R. 1988. Régimen térmico estacional de un ambiente montañoso en la Tierra del Fuego, con especial atención al límite superior del bosque. Pirinea 132:37-48.

Renard K.G., Foster G.R., Weessies G.A., Porter J.P. 1991. RUSLE: Revisited universal soil loss equation. J. Soil Water Conserv. 46:30-3.

Roberts S., Vertessy R.A., Grayson R.B. 2001. Transpiration from Eucalyptus sieberi (L. Johnson) forests of different age. Forest Ecol. Manage. 143:153-61.

Roig F. 1998. La vegetacion de la Patagonia. In: Correa M (ed.), Flora patagonica, Tomo VIII, vol. I. INTA Coleccion Cientifica, Buenos Aires, Argentina, pp 48-174.

Sarandón R., Gaviño Novillo M., Guerrero Borges V. 2007. Factors affecting the occurrence of hydrological events and subsequent damages, Draft Technical. Universidad de La Plata, Argentina, p 7.

Surrel A. 1841. Etude sur les torrents des Hautes Alpes. Carilian-Goeury et Victor Dalmont, Paris, France.

Thiery E. 1891. Restauration des montagnes, correction des torrents et reboisement. Librairie Polytechnique Ch. Beranger, Paris et Liege, France.

Vertessy R.A., Watson F., O'Sullivan S.K. 2001. Factors determining relations between stand age and catchment water balance in mountain ash forests. Forest Ecol. Manage. 143:13-26.

Williams J.R. 1975. Sediment-yield prediction with Universal Equation using run-off energy factor. Agric. Res. Serv. 40:244-52.

Wischmeier W.H., Smith D.D. 1978. Predicting rainfall erosion losses: a guide to conservation planning. Agricultural Handbook, 537. USDA, Washington, DC, USA.

Zingg A.W. 1940. Degree and length of land slope as it affects soil loss in runoff. Agric. Engine. 21:59-64. 